\title{
BUOYANT DENSITIES OF DISSOLVED AND CRYSTALLINE LACTATE DEHYDROGENASE FROM PIG HEART AND PIG MUSCLE
}

\author{
by \\ TORBEN GRAVES PEDERSEN, \\ STEPHEN BAYNE', \\ JAMES B. IFFT ${ }^{2}$ \\ and MARTIN OTTESEN \\ Department of Chemistry, Carlsberg Laboratory, \\ Gamle Carlsberg Vej 10, DK-2500 Copenhagen Valby \\ ${ }^{1}$ Present address: Fachbereich Biologie, Universität Konstanz \\ D-7050 Konstanz, West Germany \\ ${ }^{2}$ Permanent address: Department of Chemistry, \\ University of Redlands, California 92373, U.S.A.
}

Keywords: Cross-linked protein crystals, dimethylsuberimidate, cesium chloride, cesium sulfate, density gradient, equilibrium ultracentrifugation

\begin{abstract}
Buoyant densities of the $\mathrm{H}_{4}$ and $\mathrm{M}_{4}$ isoenzymes of lactate dehydrogenase from pig, in both dissolved and crystalline cross-linked states, have been determined at neutral $\mathrm{pH}$ in concentrated $\mathrm{CsCl}$ solutions by equilibrium centrifugations in an ultracentrifuge. In both states, buoyant densities of the $\mathrm{M}_{4}-\mathrm{LDH}$ were lower than those of the $\mathrm{H}_{4}-\mathrm{LDH}$, presumably due to the binding of counterions and hydration water by ten additional charged amino acid residues present on the $\mathrm{M}_{4}-\mathrm{LDH}$. The cross-linked crystals had lower buoyant densities than enzymes in dissolved state consistent with the lower density of the cross-linking reagent. The variations in buoyant densities observed in $\mathrm{CsCl}$ solutions are in agreement with a previously described model for the water- and ion-binding to proteins which assigns almost all of the bound water to the charged amino acid side chain residues. In $\mathrm{Cs}_{2} \mathrm{SO}_{4}$ solutions the buoyant densities of the $\mathrm{H}_{4}$ - $\mathrm{LDH}$ in both physical states were less than in $\mathrm{CsCl}$, probably because strongly hydrated sulphate ions bind to the charged amino acid residues.
\end{abstract}

\section{INTRODUCTION}

A previous report described the effect of cross-linking with glutaraldehyde on the buoyant density of subtilisin Carlsberg crystals (9), i.e., the density of the salt solution in which the crystals are neutrally buoyant. The variation in density found for subtilisin could be explained by means of a water- and ion-binding model deduced from experiments with ovalbumin (8). In this model all the hydration water 
was assumed to bind only to residues on the protein carrying a positive or a negative charge.

In the present paper these studies have been extended to buoyant densities of pig heart lactate dehydrogenase and pig muscle lactate dehydrogenase in both dissolved and crystalline states. Since LDH crystals are destroyed by glutaraldehyde treatment another reagent, octanediimidic acid dimethylester, was used for the cross-linking (2). This treatment caused no variations in the protein charge pattern since the positive charges on the $\varepsilon$-amino groups of lysine residues are maintained after reaction with this reagent.

\section{MATERIALS AND METHODS}

$\mathrm{M}_{4}-\mathrm{LDH}$ was obtained as a crystalline suspension from Boehringer, Mannheim. Crystalline $\mathrm{H}_{4}$-LDH was prepared from pig hearts and the crystals of the enzymes were insolubilised by cross-linking with octane-diimidic acid dimethylester as described previously (2). The cross-linking reagent was supplied by Pierce, Rockford, Illinois, as was $\mathrm{CsCl}$ ( $99.9 \%$ pure). $\mathrm{Cs}_{2} \mathrm{SO}_{4}$ (suprapure) was obtained from Merck, Darmstadt.
Ultracentrifuge measurements were performed in a Spinco Model E using schlieren optics as described for subtilisin Carlsberg (9). The resulting buoyant densities were calculated by the method of PEDERSEN \& IFFT (8).

\section{RESULTS}

Both crystalline $\mathrm{H}_{4}-\mathrm{LDH}$ and $\mathrm{M}_{4}-\mathrm{LDH}$ dissolved in the $\mathrm{CsCl}$ density gradient. From the broad bands observed at equilibrium, buoyant densities of the dissolved enzymes could be determined within $\pm 0.003 \mathrm{~g} \cdot \mathrm{ml}^{-1}$ with the results indicated in Table I.

In contrast, cross-linked crystals of $\mathrm{H}_{4}-\mathrm{LDH}$ and $M_{4}-L D H$ retained their physical characteristics throughout the course of each ultracentrifugation experiment, and formed sharp bands in the salt gradients permitting more accurate determinations of buoyant densities within \pm $0.001 \mathrm{~g} \cdot \mathrm{ml}^{-1}$ (Table I). It is seen that the buoyant densities in $\mathrm{CsCl}$ of the dissolved enzymes, 1.277 and $1.261 \mathrm{~g} \cdot \mathrm{ml}^{-1}$ for $\mathrm{H}_{4^{-}}$and $\mathrm{M}_{4}-\mathrm{LDH}$, respectively, are, in general slightly larger than those for the corresponding crosslinked crystals, 1.274 and $1.255 \mathrm{~g} \cdot \mathrm{ml}^{-1}$, respectively. For both dissolved and cross-linked en-

Table I

Buoyant densities, $\rho_{0}$, of $\mathrm{H}_{4}$ - and $\mathrm{M}_{4}-\mathrm{LDH}$ in $\mathrm{CsCl}$ and $\mathrm{Cs}_{2} \mathrm{SO}_{4}$ solutions. Experimental and calculated values.

\begin{tabular}{|c|c|c|c|c|c|c|c|}
\hline & \multicolumn{4}{|c|}{$\mathrm{CsCl}$} & \multirow{3}{*}{$\begin{array}{c}\mathrm{Cs}_{2} \mathrm{SO}_{4} \\
\mathrm{H}_{4}-\mathrm{LDH} \\
\text { exper. } \\
5\end{array}$} & \multirow[b]{3}{*}{$\begin{array}{c}\text { diff. } \\
1-3\end{array}$} & \multirow[b]{3}{*}{$\begin{array}{r}\text { diff. } \\
2-4\end{array}$} \\
\hline & \multicolumn{2}{|c|}{$\mathrm{H}_{4}-\mathrm{LDH}$} & \multicolumn{2}{|c|}{$\mathrm{M}_{\mathbf{4}}-\mathrm{LDH}$} & & & \\
\hline & $\begin{array}{c}\text { exper. } \\
1\end{array}$ & $\begin{array}{c}\text { calc. } \\
2\end{array}$ & $\begin{array}{c}\text { exper. } \\
3\end{array}$ & $\begin{array}{c}\text { calc. } \\
4\end{array}$ & & & \\
\hline $\begin{array}{l}\text { Dissolved } \\
\text { enzymes }\end{array}$ & 1.277 & 1.286 & 1.261 & 1.272 & 1.232 & 0.016 & 0.014 \\
\hline $\begin{array}{l}\text { Cross-linked } \\
\text { crystals }\end{array}$ & 1.274 & 1.282 & 1.255 & 1.269 & 1.226 & & \\
\hline Difference & 0.003 & 0.004 & 0.006 & 0.003 & 0.006 & & \\
\hline
\end{tabular}

Abbreviations: $\mathrm{H}_{4}-\mathrm{LDH}=$ pig heart lactate dehydrogenase; $\mathrm{M}_{4}-\mathrm{LDH}=$ pig muscle lactate dehydrogenase. 
zymes the buoyant densities of the $\mathrm{H}_{4}$-LDH were larger than those of the $\mathrm{M}_{4}-\mathrm{LDH}$.

In the experiment with dissolved $\mathrm{H}_{4}-\mathrm{LDH}$ in $\mathrm{CsCl}$ gradient, a small amount of the enzyme precipitated. The buoyant density of this protein, which presumably was denatured, was larger $\left(1.288 \mathrm{~g} \cdot \mathrm{ml}^{-1}\right)$ than the density of the dissolved protein $\left(1.277 \mathrm{~g} \cdot \mathrm{ml}^{-1}\right)$, as has previously been observed with denatured and dissolved ovalbumin $(4,8)$.

Buoyant densities of $\mathrm{H}_{4}-\mathrm{LDH}$ in the two physical states, were also determined in $\mathrm{Cs}_{2} \mathrm{SO}_{4}$ solutions (Table I). They were lower for both dissolved and cross-linked enzymes than for the identical isoenzymes in $\mathrm{CsCl}$ solutions and it was again observed that the buoyant density of the cross-linked form was lower than the density of the dissolved form. In $\mathrm{Cs}_{2} \mathrm{SO}_{4}$ solution no band of insoluble, denatured protein was observed.

\section{DISCUSSION}

It is well known that the buoyant density of a protein as determined in $\mathrm{CsCl}$ gradients, increases with increasing $\mathrm{pH}$, especially in the $\mathrm{pH}$ regions from 3 to 5 and from 9 to $11(4,10)$. Thus, the increase in density in the first $\mathrm{pH}$ range parallels deprotonation of Asp and Glu with concomitant binding of heavy cesium ions, while the density increase at $\mathrm{pH} 9$ to 11 parallels release of light chloride ions from lysine residues losing their positive charges.
Buoyant titration experiments performed with ovalbumin in four alkali halide salt solutions made it possible to formulate a model which ascribed to each charged amino acid residue on the protein, an oppositely charged salt ion plus a corresponding amount of hydration water, as indicated in reference (8). This model is expressed in equation [1] where $M_{p}$ is the molecular weight of the protein, $\bar{v}$ its partial specific volume, $n_{c}$ and $n_{a}$ are the number of moles of cations and anions bound, respectively, and $\mathrm{W}_{\mathrm{c}}, \mathrm{W}_{\mathrm{a}}, \mathrm{V}_{\mathrm{c}}$ and $\mathrm{V}_{\mathrm{a}}$ are the corresponding molar weights and the molar volumes, respectively, of the hydrated cationic and anionic charge-ion complexes.

$$
P_{b}=\frac{M_{p}+n_{c} W_{c}+n_{a} W_{a}}{M_{p} \bar{V}_{p}+n_{c} V_{c}+n_{a} V_{a}} \quad \text { [1] }
$$

In the equation the denominator expresses the weight in grams of the protein plus bound hydrated cations plus bound hydrated anions, and the nominator is the sum of the volumes in milliliters of the same three components. Although there is no term for water bound to the protein surface at other places than at the charged residues the equation adequately describes the observed buoyant densities (8). The buoyant densities of dissolved and crystalline subtilisin Carlsberg were found also to agree with equation [1] (9).

The generality of this equation has in the present paper been examined by extending it to the

Table II

Molecular weights, partial specific volumes, ion hinding and hydration data for $\mathrm{H}_{4}-\mathrm{LDH}$ and $\mathrm{M}_{4}-\mathrm{LDH}$.

\begin{tabular}{lcccccccc}
\hline & $\begin{array}{c}\mathrm{M}_{\mathrm{p}} \\
\text { dalton }\end{array}$ & $\begin{array}{c}\overline{\mathrm{v}}_{\mathrm{p}} \\
\mathrm{ml} \cdot \mathrm{g}^{-1}\end{array}$ & $\mathrm{n}_{\mathrm{c}}$ & $\mathrm{n}_{\mathrm{a}}$ & $\begin{array}{c}\mathrm{W}_{\mathrm{c}} \\
\mathrm{g}\end{array}$ & $\begin{array}{c}\mathrm{w}_{\mathrm{a}} \\
\mathrm{g}\end{array}$ & $\begin{array}{c}\mathrm{V}_{\mathrm{a}} \\
\mathrm{ml}\end{array}$ & $\begin{array}{c}\mathrm{V}_{\mathrm{a}} \\
\mathrm{ml}\end{array}$ \\
\hline $\mathrm{H}_{4}$ & 36480 & 0.749 & 33 & 35 & 424 & 267 & 311 & 255 \\
$\mathrm{M}_{4}$ & 36510 & 0.751 & 35 & 43 & 433 & 269 & 320 & 258 \\
\hline
\end{tabular}

$M_{p}, n_{c}$ and $n_{a}$ are determined from the amino acid compositions in KILTZ et al. (6). $\bar{v}_{p}$ values were calculated by the method of COHN and EDSALl (3). $W_{c}, W_{a}, V_{c}$ and $V_{a}$ are taken from Figure 4 in PEDERSEN and IFFT (8), where the water activities, $a_{1}$, corresponding to the buoyant densities, $\rho_{0}$, are taken from PEDERSEN et al. (7). The listed values for $W_{c}$ indicates 16.2 and 16.7 moles of water to be bound to the hydrated cesium counter ion complex and the corresponding $W_{a}$ values indicate 12.9 and 13.0 moles of water per mole hydrated chloride counter ion complex in $\mathrm{H}_{4}$ - and $\mathrm{M}_{4}-\mathrm{LDH}$, respectively. 
buoyant densities of $\mathrm{H}_{4}-\mathrm{LDH}$ and $\mathrm{M}_{4}-\mathrm{LDH}$. When the relevant data as listed in Table II are inserted in equation [1], it is seen (Table I) that the calculated buoyant densities are larger than those determined experimentally. However, this difference is relatively small since it corresponds to an additional binding of only about 80 water molecules to the ca. 1000 water molecules bound to the charged amino acid residues and their counter ions as estimated from the data in Table II. This discrepancy is regarded as being within the limit of error arising from the calculated value of $\bar{v}$. Consequently, in LDH as in ovalbumin (8) and subtilisin (9) it is reasonable to assume that essentially all of the bound water is associated with the charged residues on the surface of the protein molecules.

In comparison with $\mathrm{H}_{4}-\mathrm{LDH}, \mathrm{M}_{4}-\mathrm{LDH}$ has 2 additional positive charges and 8 additional negative charges at $\mathrm{pH} 7$ (6). According to Table II and equation [1] this should result in a decrease in density of 0.014 which is in agreement with the experimentally observed difference of $0.016 \mathrm{~g} \cdot \mathrm{ml}^{-1}$ (Table I).

The calculation of the buoyant densities of the cross-linked LDH crystals required a modified form of equation [1] which includes the molar weight, $W_{0}$, the molar volume, $V_{0}$, and the number of moles, $y$, of the incorporated crosslinking residue per mole of protein present in the crystals:

$$
\rho_{0}=\frac{M_{p}+n_{c} W_{c}+n_{a} W_{a}+y W_{0}}{M_{p} \bar{V}_{p}+n_{c} V_{c}+n_{a} V_{a}+y V_{0}}
$$

This equation is somewhat simpler than the modified equation used for cross-linked subtilisin crystals (9), because the LDH crosslinking reagent is bound to lysine residues in such a way that the positive charges are maintained. The two $\mathrm{LDH}$ isoenzymes crystals were cross-linked to similar extent (each having 12 lysine residues modified, determined by amino acid analysis (1), viz. $y=12$ ) by the reaction:

$$
\begin{aligned}
& \mathrm{CH}_{3} \mathrm{O}-\mathrm{C}\left(=\stackrel{+}{\mathrm{NH}} \mathrm{H}_{2}\right)\left(\mathrm{CH}_{2}\right)_{6} \mathrm{C}\left(=\stackrel{+}{\mathrm{NH}_{2}}\right)-\mathrm{OCH}_{3}+2 \text { enz- } \stackrel{+}{\mathrm{N}} \mathrm{H}_{3} \\
& \rightarrow \text { enz- } \stackrel{+}{\mathrm{N} H}-\mathrm{C}(=\mathrm{NH})\left(\mathrm{CH}_{2}\right){ }_{6} \mathrm{C}(=\mathrm{NH})-\stackrel{+}{\mathrm{N}} \mathrm{H}_{2}-\mathrm{enz}
\end{aligned}
$$

The molar weight, $W_{0}$, of the incorporated cross-linking reagent was $136 \mathrm{~g}$ and the molar volume, $\mathrm{V}_{\mathrm{o}}, 119 \mathrm{ml}$, calculated according to TRAUBE (11). Thus, the cross-linking residue has a lower density $\left(W_{o} V_{o}=1.14 \mathrm{~g} \cdot \mathrm{ml}^{-1}\right)$ than the $\mathrm{LDH}$ isoenzymes (1.277 and $1.261 \mathrm{~g} \cdot \mathrm{ml}^{-1}$ for $\mathrm{H}_{4}-\mathrm{LDH}$ and $\mathrm{M}_{4}-\mathrm{LDH}$, respectively), and the buoyant density should decrease upon the cross-linking reaction. These decreases in buoyant density between dissolved enzyme and cross-linked crystals are calculated for $\mathrm{H}_{4}-\mathrm{LDH}$ and $\mathrm{M}_{4}-\mathrm{LDH}$, respectively, to be 0.004 and $0.003 \mathrm{~g} \cdot \mathrm{ml}^{-1}$ in reasonable agreement with the experimentally found differences of 0.003 and $0.006 \mathrm{~g} \cdot \mathrm{ml}^{-1}$ (Table I).

The much lower buoyant densities of soluble and cross-linked $\mathrm{H}_{4}-\mathrm{LDH}$ in $\mathrm{Cs}_{2} \mathrm{SO}_{4}$ solutions (relative to those determined in $\mathrm{CsCl}$ solutions) could not be compared with calculated values since data for $\mathrm{W}_{\mathrm{a}}$ and $\mathrm{V}_{\mathrm{a}}$ of the sulphate ion are lacking. Still, the decrease in buoyant density agrees with the results of IFFT and VINOGRAD (5) who found that the buoyant densities of serum mercaptalbumin in $\mathrm{CsCl}$ and $\mathrm{Cs}_{2} \mathrm{SO}_{4}$ solutions were 1.278 and $1.237 \mathrm{~g} \cdot \mathrm{ml}^{-1}$, respectively. A possible explanation of the low buoyant density in $\mathrm{Cs}_{2} \mathrm{SO}_{4}$ solutions could be an increased hydration of the counter ions bound to the charged protein residues.

Because of the uncertainty in the $\bar{v}$ value for a protein, due to either an insufficient method of calculation or to an uncertainty in the determination of the weight of the pure protein used for an experiment, differences between calculated and experimental buoyant densities are to be expected. However, the proposed simple ion- and water binding model shows its usefulness by explaining the buoyant density differences which arise from variations in the number of charged amino acid residues resulting in differences in the amounts of counter ions and water bound.

\section{ACKNOWLEDGEMENTS}

The authors wish to thank IB SVENDSEN for valuable discussions and BODIL CORNELIUSSEN for performing the amino acid analyses.

\section{REFERENCES}

1. BAYNe, S. J. \& M. OTtesen: Enzymatically active, cross-linked pig heart lactate dehydrogenase crystals. Carlsberg Res. Commun. 41, 211-216 (1976) 
2. BaYNe, S. J. \& M. OTtesen: Properties of lactate dehydrogenase crystals reacted with diimidoesters. Carlsberg Res. Commun. 42, 465-474 (1977)

3. COHN, E. J. \& J. T. EDSALL: Density and apparent specific volume of proteins. In: Proteins, amino acids and peptides as ions and dipolar ions. Capter 16, p372. Reinhold, New York (1943)

4. IFFT, J. B.: The buoyant titration of native and carbamylated ovalbumin. Compt. Rend. Trav. Lab. Carlsberg 38, 315-338 (1971)

5. IFFT, J. B. \& J. VINOGRAD: The buoyant behavior of bovine serum mercaptalbumin in salt solutions at equilibrium in the centrifuge. II. Net hydration, ion binding, and solvated molecular weight in various salt solutions. J. Phys. Chem. 70, 2814-2822 (1966)

6. Kiltz, H., W. KeIl, M. Griesbach, K. Petry \& H. MEYER: The primary structure of porcine lactate dehydrogenase: Isoenzymes $\mathrm{M}_{4}$ and $\mathrm{H}_{4}$.
Hoppe-Seyler's Z.Physiol.Chem. 358, 123-127 (1977)

7. Pedersen, T. G., L. Sejersen \& J. B. Ifft: The partial molar volumes of six alkali halides and their jons as a function of concentration. Carlsberg Res. Commun. 42, 211-224 (1977)

8. Pedersen, T. G. \& J. B. IfFt: Buoyant titration of ovalbumin in four alkali halides. Hydration and ion binding. Carlsberg Res. Commun. 43, 65-76 (1978)

9. Pedersen, T. G., E. Tuchen, I. Svendsen \& M. OTTESEN: Buoyant densities of subtilisin Carlsberg in dissolved and crystalline states. Carlsberg Res. Commun. 43, 219-225 (1978)

10. RUARK, J. E. \& J. B. IFFT: The buoyant and potentiometric titrations of human Immunogamma Globulin. Biopolymers 14, 1161-1171 (1975)

11. Traube, J.: Ueber den raum der atome. Samm. Chem.-Tech. Vorträge 4, 255-332 (1899) 